Abstracta Iranica

Revue bibliographique pour le domaine irano-aryen

Volume 34-35-36 | 2017

Comptes rendus des publications de 2011-2013

\title{
Baruch Brandl. Three Persian-Period Metallic Finger Rings from Burial Cave 2, South Horbat Tittora
}

\section{Astrid Nunn}

\section{(2) OpenEdition}

10 Journals

Édition électronique

URL : http://journals.openedition.org/abstractairanica/41633

DOI : 10.4000/abstractairanica.41633

ISSN : 1961-960X

\section{Éditeur :}

CNRS (UMR 7528 Mondes iraniens et indiens), Éditions de l'IFRI

\section{Référence électronique}

Astrid Nunn, «Baruch Brandl. Three Persian-Period Metallic Finger Rings from Burial Cave 2, South Horbat Tittora », Abstracta Iranica [En ligne], Volume 34-35-36 | 2017, document 61, mis en ligne le 15 juillet 2016, consulté le 28 septembre 2020. URL : http://journals.openedition.org/abstractairanica/41633 ; DOI : https://doi.org/10.4000/abstractairanica.41633

Ce document a été généré automatiquement le 28 septembre 2020.

Tous droits réservés 


\title{
Baruch Brandl. Three Persian-Period Metallic Finger Rings from Burial Cave 2, South Horbat Tittora
}

\author{
Astrid Nunn
}

\section{RÉFÉRENCE}

Baruch Brandl. « Three Persian-Period Metallic Finger Rings from Burial Cave 2, South Horbat Tittora ». 'Atiqot, 72, 2012, p. 33-40.

1 Ḥorbat Tittora est une fouille de sauvetage située à mi-chemin entre Tel Aviv et Jérusalem. Plusieurs tombes y ont été fouillées et trois bagues se trouvaient dans la "Burial Cave 2". Leur forme est simple mais les deux chatons en forme de tête de lion (bague en fer) et de deux capridés courant dont l'un serait ailé (bague en bronze) sont particuliers. Forme et motif renvoient à l'art achéménide.

\section{AUTEURS}

\section{ASTRID NUNN}

Université de Munich 